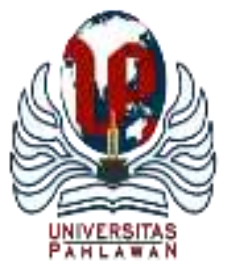

Edukatif : Jurnal Ilmu Pendidikan Volume 3 Nomor 6 Tahun 2021 Halm 4025 - 4040

EDUKATIF: JURNAL ILMU PENDIDIKAN

Research \& Learning in Education

https://edukatif.org/index.php/edukatif/index

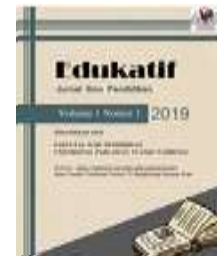

\title{
Quo Vadis Motivasi Intrinsik Pegawai: Peran Strategis Kepemimpinan Transformasional dan Kepuasan Kerja
}

\author{
Muhamad Agung Ali Fikri ${ }^{1 凶}$, Masduki Asbari², Dhaniel Hutagalung ${ }^{3}$, Lala Hucadinota Ainul \\ Amri $^{4}$, Dewiana Novitasari ${ }^{5}$ \\ Sekolah Tinggi Ilmu Ekonomi Insan Pembangunan, Indonesia ${ }^{1,3,5}$ \\ STMIK Insan Pembangunan, Indonesia ${ }^{2}$ \\ Politeknik Negeri Media Kreatif, Indonesia ${ }^{4}$ \\ E-mail : agungkuw@gmail.com ${ }^{1}$, kangmasduki.ssi@gmail.com $^{2}$, dhanielhutagalung@gmail.com $^{3}$, \\ $\underline{\text { lalahuca@polimedia.ac.id }}{ }^{4}$ dhewiediosa@yahoo.co.id $^{5}$
}

\begin{abstract}
Abstrak
Memotivasi pegawai di era Revolusi Industri 4.0 untuk meraih kinerja yang lebih baik adalah masalah utama bagi perusahaan manufaktur saat ini, lebih-lebih di saat pandemic, perusahaan masih terus berjuang untuk tetap eksis di masa krisis ini. Studi ini menyelidiki apakah praktik kepemimpinan transformasional mempengaruhi motivasi intrinsik pegawai, sekaligus mempertimbangkan efek mediasi dari variable basic need satisfaction. Data dikumpulkan dari 109 karyawan salah satu industri manufaktur swasta di Jawa Barat dengan menggunakan metode kuantitatif dan survei konfirmasi dengan bantuan software SmartPLS 3.0. Studi ini menunjukkan bahwa praktik kepemimpinan transformasional memberikan pengaruh positif dan signifikan terhadap motivasi intrinsik pegawai, baik secara langsung maupun tidak langsung melalui mediasi basic need satisfaction. Hasil penelitian ini dapat memiliki implikasi yang signifikan terhadap pengambilan keputusan manajerial SDM tentang praktik kepemimpinan transformasional di lingkungan karyawan industri manufaktur di Indonesia. Di samping itu, studi ini juga membantu manajemen SDM industri manufaktur untuk serius menilai rencana investasi pengembangan SDM dalam bentuk implementasi praktik kepemimpinan transformasional untuk bertahan di era digital ini.
\end{abstract}

Kata kunci: Basic need satisfaction, kepemimpinan transformasional, motivasi intrinsik.

\begin{abstract}
Motivating employees in the Industrial Revolution 4.0 era to achieve greater efforts is a major problem for today's manufacturing companies that continue to struggle to exist in this time of crisis. Transformational leadership is suggested as an important lever in this regard because its essence concerns the behavior to develop, share, and maintain a vision for the organization. This study investigates whether transformational leadership practices affect employees' intrinsic motivation while considering the mediating effect of basic need satisfaction. Data were collected from 109 employees of the private manufacturing industry in West Java using quantitative methods and confirmation surveys with the help of SmartPLS software. This study shows that the practice of transformational leadership has a positive and significant influence on employee intrinsic motivation, either directly or indirectly through the mediation of basic need satisfaction. The results of this study could have significant implications for HR managerial decisionmaking regarding transformational leadership practices in manufacturing industry employees in Indonesia. In addition, this study also helps the HR management of the manufacturing industry to seriously assess the investment plan for HR development in the form of transformational leadership practices to survive in this digital era.
\end{abstract}

Keywords: Basic need satisfaction, transformational leadership, intrinsic motivation.

Copyright (c) 2021 Muhamad Agung Ali Fikri, Masduki Asbari, Dhaniel Hutagalung, Lala Hucadinota Ainul Amri, Dewiana Novitasari

$\triangle$ Corresponding author:

Email : agungkuw@gmail.com

DOI : https://doi.org/10.31004/edukatif.v3i6.1397 
4026 Quo Vadis Motivasi Intrinsik Pegawai: Peran Strategis Kepemimpinan Transformasional dan Kepuasan Kerja - Muhamad Agung Ali Fikri, Masduki Asbari, Dhaniel Hutagalung, Lala Hucadinota Ainul Amri, Dewiana Novitasari

DOI: https://doi.org/10.31004/edukatif.v3i6.1397

\section{PENDAHULUAN}

Menumbuhkan motivasi kerja itu penting, karena motivasi kerja telah dikaitkan dengan kepuasan kerja (Nugroho et al., 2021). Di saat terjadi kelangkaan sumber daya manusia unggul dan tuntutan terus menerus untuk motivasi intrinsik yang lebih tinggi, kemampuan untuk meningkatkan motivasi kerja mungkin terbukti merupakan cara penting bagi organisasi publik untuk mencapai tujuan organisasi, sambil menjaga karyawan tetap puas dengan pekerjaannya (Admiral et al., 2021; Chidir et al., 2021; Hutagalung et al., 2021; Nadeak et al., 2021; Waruwu et al., 2021). Dalam literatur administrasi bisnis, fokus telah dipusatkan pada konsep motivasi pelayanan (Asbari et al., 2021b, 2021a). Didefinisikan sebagai orientasi individu untuk memberikan layanan kepada orang-orang dengan tujuan berbuat baik bagi orang lain dan masyarakat (Al-Ibrahim, 2014; Jensen \& Bro, 2018). Motivasi pelayanan tidak hanya mendorong karyawan untuk melakukan upaya menuju tugas yang menarik dan menyenangkan dengan konsekuensi prososial, tetapi juga membantu menjelaskan mengapa karyawan melakukan upaya ekstra tugas-tugas yang secara inheren tidak menyenangkan atau tidak memberi insentif dengan imbalan uang, membuatnya making penting bagi para pemimpin bisnis untuk mengetahui bagaimana merangsang motivasi ini. Di sisi lain, praktik kepemimpinan transformasional memerlukan perilaku yang bertujuan untuk mengarahkan dan mengilhami upaya untuk memenuhi organisasi tujuan dengan mengartikulasikan visi yang meningkatkan kesadaran karyawan terhadap pentingnya nilai-nilai organisasi, misi, dan hasil (Johan et al., 2021a; Jumiran et al., 2020; Novitasari, Asbari, Putra, et al., 2021; Pramono et al., 2021). Oleh karena itu, strategi kepemimpinan ini adalah semakin diakui dalam literatur administrasi bisnis sebagai anteseden penting dari motivasi (Anggraeni et al., 2020; Asbari et al., 2019; Johan et al., 2021b; Novitasari, Haque, Supriatna, et al., 2021a; Nugroho et al., 2020; Purwanto; et al., 2019). Harapan inti dalam teori kepemimpinan transformasional adalah bahwa transformasional pemimpin "mengaktifkan kebutuhan tingkat tinggi dari karyawan" (Jensen \& Bro, 2018), tetapi harapan ini perlu diuji di industry manufaktur, karena masih adanya keterbatasan studi yang mengeksplorasi hal ini.

Dalam studi ini, peneliti membangun wawasan dari Self-Determination Theory (SDT), karena memperkenalkan pentingnya kebutuhan (untuk otonomi, kompetensi, dan keterkaitan) kepuasan dan menawarkan kerangka kerja untuk membedakan berbagai jenis motivasi (Deci et al., 2017; Goldman et al., 2017; Manganelli et al., 2018; Rezvani et al., 2017; Ryan \& Deci, 2020). Memperkenalkan pemenuhan kebutuhan dasar sebagai mekanisme mediasi antara kepemimpinan transformasional dan berbagai jenis motivasi kerja mandiri penting karena beberapa alasan: Pertama, memahami mekanisme psikologis melalui mana kepemimpinan organisasi dapat meningkatkan atau menggagalkan motivasi kerja karyawan sangat penting bagi manajer. Idealnya, manajer dapat menggunakan informasi tersebut dalam keputusan tentang cara memotivasi karyawan untuk mencapai tujuan organisasi. Kedua, motivasi adalah konsep multifaset (AlMansoori \& Koç, 2019), dan berbagai jenis motivasi kerja mungkin bermanfaat bagi mencapai hasil yang diinginkan yang berbeda (F. Putra et al., 2021; Sudiyono et al., 2020). Akibatnya, para ahli memberikan gambaran yang lebih lengkap tentang efek motivasi dengan memasukkan berbagai jenis pekerjaan motivasi secara bersamaan dalam studi empiris. Memeriksa jenis motivasi kerja otonom, yakni motivasi intrinsicstudi ini menjawab panggilan tersebut dengan menawarkan gambaran yang lebih lengkap tentang bagaimana memotivasi karyawan melalui kepemimpinan transformasional. Ketiga dan terakhir, mengintegrasikan teori SDT, kepemimpinan transformasional, dan motivasi memiliki potensi untuk menjelaskan bagaimana praktik kepemimpinan dapat membentuk persepsi karyawan. Model yang diajukan dalam studi ini masih sangat jarang ditemui dalam kajian-kajian peneliti terdahulu, lebih-lebih yang diimplementasikan pada unit analisis industry manufaktur di negara berkembang seperti Indonesia.

Menurut literatur kepemimpinan transformasional tradisional, pemimpin transformasional mengarahkan dan menginspirasi karyawan dengan mengartikulasikan visi yang meningkatkan kesadaran dan pemahaman 
4027 Quo Vadis Motivasi Intrinsik Pegawai: Peran Strategis Kepemimpinan Transformasional dan Kepuasan Kerja - Muhamad Agung Ali Fikri, Masduki Asbari, Dhaniel Hutagalung, Lala Hucadinota Ainul Amri, Dewiana Novitasari

DOI: https://doi.org/10.31004/edukatif.v3i6.1397

karyawan tentang pentingnya nilai organisasi, misi, dan hasil (Bogler, 2001). Akibatnya, pusat teori tentang kepemimpinan transformasional adalah penekanan kuat pada peran visi kolektif yaitu, seperangkat tujuan ideal yang dicita-citakan organisasi untuk dicapai. Alhasil, komponen visioner menjadi inti dari konseptualisasi kepemimpinan transformasional dalam literatur manajemen kontemporer dan penelitian administrasi bisnis. Selanjutnya, para pemimpin transformasional berusaha untuk mengkomunikasi visi organisasi kepada karyawan. Ini termasuk menetapkan hubungan antara visi dan tugas kerja sehari-hari, untuk membuat karyawan individu memahami bagaimana mereka berkontribusiu ntuk hasil yang ditetapkan oleh organisasi mereka. Akhirnya, pemimpin transformasional berusaha untuk mempertahankan karyawan yang memperhatikan visi, baik dalam jangka pendek maupun jangka panjang, juga mendorong karyawan untuk bekerja menuju visi yang ditunjuk (Asbari, 2020; Asbari \& Novitasari, 2020; Novitasari et al., 2021; Purwanto, Asbari, \& Santoso, 2019). Selanjutnya, studi ini mengacu pada SDT untuk untuk memperdebatkan bagaimana basic need satisfaction memediasi hubungan antara kepemimpinan transformasional dan motivasi intrinsik.

\section{Motivasi Intrinsik dari Perspektif Self-Determination}

Menurut SDT, orang tidak hanya berbeda dalam hal bagaimana banyak motivasi yang mereka miliki untuk melakukan suatu kegiatan tetapi juga dalam hal jenis motivasi di balik tindakan (Rigby \& Ryan, 2018). Perbedaan mendasar dalam teori antara motivasi intrinsik dan motivasi terkontrol, ditentukan oleh apakah motivasi itu melibatkan "rasa" kemauan dan memiliki pengalaman memilih atau "perasaan" tekanan dan harus terlibat dalam tindakan" (Rigby \& Ryan, 2018). Jenis-jenis motivasi dapat dilihat sebagai bagian dari kontinum motivasi, di mana motivasi intrinsik adalah prototipikal otonom (Gagné \& Deci, 2005). Merujuk apakah suatu kegiatan dipandang secara inheren menarik atau menyenangkan (Rigby \& Ryan, 2018), motivasi intrinsik dikontraskan dengan jenis motivasi ekstrinsik lainnya, yang membutuhkan semacam alat antara aktivitas dan yang dapat dipisahkan hasil (Gagné \& Deci, 2005). Ketika kegiatan tersebut dilakukan karena konsekuensi eksternal (atau "seolah-olah" eksternal). (seperti persetujuan implisit, imbalan nyata, atau meningkatkan harga diri), motivasi dikatakan ekstrinsik. Namun, ketika regulasi perilaku, dan nilai yang terkait dengannya, telah diinternalisasi ke sejauh konsekuensi eksternal tidak lagi diperlukan, motivasi dikatakan intrinsic (Gagné \& Deci, 2005). Menurut SDT, hal terakhir ini terjadi ketika orang mengidentifikasi dengan nilai aktivitas (tidak menyenangkan) untuk tujuan yang mereka pilih sendiri, atau bahkan melihat perilaku sebagai bagian integral dari siapa mereka (tujuan, nilai, dan peraturan) dari suatu perilaku yang koheren dengan aspek-aspek lain dari kehidupan seseorang (Gagné \& Deci, 2005).

Menurut SDT, basic need satisfaction sangat penting untuk internalisasi dan pemeliharaan motivasi intrinsik (Gagné \& Deci, 2005). Basic need satisfaction juga telah dianggap sebagai fitur inti dari teori kepemimpinan transformasional (Podsakoff et al., 1990). Argumen ini disampaikan oleh Ramsey et al. (2017), yang menyatakan bahwa untuk mengarahkan dan menginspirasi upaya individu, pemimpin [transformasional] perlu mengubah pengikut mereka dengan meningkatkan kesadaran mereka terhadap pentingnya hasil organisasi, sehingga mengaktifkan kebutuhan mereka yang lebih tinggi dan mendorong mereka untuk melampaui kebutuhan terhadap kepentingan diri sendiri untuk kepentingan organisasi. Oleh karena itu, peneliti berpendapat bahwa SDT dan gagasannya tentang basic need satisfaction adalah komponen yang diperlukan untuk memahami bagaimana kepemimpinan transformasional menumbuhkan motivasi intrinsik mereka.

\section{Kepemimpinan Transformasional dan Motivasi Intrinsik: Peran Mediasi Basic need satisfaction}

Kebutuhan akan otonomi menyangkut pengalaman memilih dan merasa sebagai penggagas atas tindakan sendiri (Ryan \& Deci, 2020). Sedangkan kepemimpinan transformasional, berusaha untuk memperjelas tujuan pekerjaan karyawan, yang pada gilirannya membuat karyawan mengalami pekerjaan 
4028 Quo Vadis Motivasi Intrinsik Pegawai: Peran Strategis Kepemimpinan Transformasional dan Kepuasan Kerja - Muhamad Agung Ali Fikri, Masduki Asbari, Dhaniel Hutagalung, Lala Hucadinota Ainul Amri, Dewiana Novitasari

DOI: https://doi.org/10.31004/edukatif.v3i6.1397

mereka sebagai bermakna (Al-Mansoori \& Koç, 2019). Membangun tujuan dan sasaran organisasi dalam konteks visi yang lebih luas, menjadikan karyawan tidak lagi memerlukan (secara terus menerus) pedoman mengenai apakah tindakan tersebut mendukung tujuan organisasi atau tidak. Selain itu, kepemimpinan transformasional membedakan dirinya dari perilaku kepemimpinan yang berfokus pada pemantauan ketat tindakan karyawan (misalnya, untuk menghargai atau menghukum karyawan) dengan tidak adanya "micromanagement " yang digunakan untuk memastikan bahwa karyawan tidak mengejar agenda yang berbeda.

Beberapa penelitian yang ada menguatkan perspektif ini, menunjukkan korelasi positif antara transformasional kepemimpinan dan kepuasan kebutuhan akan otonomi (Hetland et al., 2011; Kovjanic et al., 2013; Kovjanic et al., 2012). Dengan demikian, para pemimpin transformasional membangkitkan rasa kepuasan kebutuhan akan otonomi dengan (a) secara jelas menetapkan tujuan organisasi yang lebih luas, memungkinkan karyawan untuk memulai tugas sehari-hari yang berkontribusi pada hasil yang ditentukan; dan (b) menghindari manajemen mikro seperti pemantauan keta tatas tindakan karyawan atau menetapkan tujuan yang sangat spesifik untuk mengarahkan tugas sehari-hari individu karyawan. Oleh karena itu peneliti menduga bahwa kepemimpinan transformasional mampu meningkatkan kepuasan karyawan akan kebutuhan otonomi dan basic need satisfaction.

Selanjutnya, kebutuhan akan kompetensi yang menyangkut keberhasilan dalam tugas yang menantang, mampu mencapai hasil yang diinginkan adalah pusat perasaan kompetensi di antara para karyawan (Asbari, Santoso, et al., 2020; Asbari \& Novitasari, 2020; Maesaroh et al., 2020; Novitasari, Goestjahjanti, \& Asbari, 2020; Zaman et al., 2020), sesuatu yang terkait erat dengan perasaan efikasi diri dalam tempat kerja. Perasaanperasaan di atas mampu diartikulasikan oleh seorang pemimpin transformasiomal, karena kemampuan jenis kepemimpinan ini adalah mengartikulasikan dan mengomunikasikan keadaan akhir masa depan yang diinginkan dari organisasi (visi) dan menetapkan bagaimana pekerjaan karyawan berkontribusi terhadap capaian hasil yang ditentukan. Pemimpin transformasional menetapkan tujuan yang diinginkan dan mengungkapkan keyakinan bahwa tujuan tersebut dapat dicapai oleh karyawan melalui pekerjaannya. Demikian juga kebutuhan akan keterkaitan yang mengacu pada keinginan untuk merasakan terhubung dengan orang lain; yaitu, untuk "membangun rasa saling rasa hormat dan ketergantungan dengan orang lain" (Jensen \& Bro, 2018). Mendorong karyawan untuk "menarik" ke arah yang sama untuk mencapai hasil yang ditentukan terkait dengan tujuan organisasi. Lagi-lagi, pada kondisi seperti ini, pemimpin transformasional dapat membangkitkan perasaan dalam kelompok dan rasa terhubung dengan orang lain dalam pekerjaan.

\section{METODE PENELITIAN}

Penelitian ini mengadopsi teknik survei dengan menggunakan analisis kuantitatif dan untuk mengumpulkan data tentang pengaruh kepemimpinan transformasional terhadap motivasi intrinsik karyawan, baik secara langsung maupun tidak langsung melalui mediasi basic need satisfaction. Survei memungkinkan para peneliti untuk mengumpulkan data dari karyawan yang berpartisipasi dalam sesi training kepemimpinan yang dilakukan oleh atasan mereka, dan membantu mereka dalam menilai motivasi intrinsik karyawan yang dirasakan. Teknik ini diadopsi karena kemampuannya untuk mengumpulkan data dengan cepat dibandingkan dengan alat lain, sementara memungkinkan pemilihan sampel secara acak, dan memungkinkan peneliti untuk mengukur dan mengontrol beberapa variabel. Setelah itu, untuk mengidentifikasi temuan atau pola dalam sampel terkait, data yang terkumpul kemudian dianalisis secara mendalam. Tujuan dari penelitian ini adalah untuk mengumpulkan pengetahuan yang berguna secara maksimal untuk membentuk hipotesis yang valid, yang meminimalisir subjektifitas. Dengan demikian, teori positivis diadopsi dalam penelitian ini karena mengidentifikasi kesamaan yang terlihat melalui observasi dan investigasi kerja. Oleh karena itu, pendekatan deduktif diikuti, berusaha untuk mengusulkan dan menguji hipotesis untuk menyesuaikan teori yang ada. 
4029 Quo Vadis Motivasi Intrinsik Pegawai: Peran Strategis Kepemimpinan Transformasional dan Kepuasan Kerja - Muhamad Agung Ali Fikri, Masduki Asbari, Dhaniel Hutagalung, Lala Hucadinota Ainul Amri, Dewiana Novitasari

DOI: https://doi.org/10.31004/edukatif.v3i6.1397

Untuk kepentingan penelitian ini, kuesioner dirancang dalam beberapa bagian: Bagian pertama mencakup pertanyaan demografis di mana karyawan secara anonim nyatakan jenis kelamin, usia, pendidikan, dan masa kerja perusahaan. Bagian kedua mencakup lima pertanyaan yang menangkap sejauh mana kepemimpinan transformasional dipraktikkankan di perusahaan. Item pengukuran (KEP1-KEP5) ini diambil dari Bogler (2001). Instrumen yang digunakan untuk mengukur basic need satisfaction diadaptasi dari Law et al. (2004) dengan menggunakan 6 item (BNS1-BNS6). Sedangkan instrumen yang digunakan untuk mengukur motivasi intrinsik karyawan diadaptasi dari Lin \& Peng (2010) dengan menggunakan 3 item (MOT1-MOT3). Kuesioner dirancang sedemikian rupa untuk menargetkan karyawan di salah satu industri manufaktur di Jawa Barat. Untuk memastikan kecukupan alat penelitian sesuai konteks, peneliti meneruskan kuesioner kepada empat peneliti yang catatannya kemudian dimasukkan. Selanjutnya, kuesioner diujicobakan pada 30 karyawan. Para peneliti mengumpulkan data secara anonim sesuai dengan standar etika penelitian dan dapat menerima tingkat tanggapan yang cukup besar melalui komunikasi online. Lebih detil tentang item kuesioner penelitian ini bisa dilihat pada Tabel 1.

\section{Tabel 1}

Daftar Item Penelitian

\begin{tabular}{lll}
\hline Notasi & Item & Referensi \\
\hline \multicolumn{2}{l}{ Kepemimpinan Transformasional (KEP) } & Bogler \\
KEP1 & Pimpinan saya memproyeksikan dirinya sebagai panutan & $(2001)$ \\
KEP2 & $\begin{array}{l}\text { Pimpinan saya menunjukkan bakat dan kemampuan untuk mengatasi } \\
\text { pengambilan keputusan }\end{array}$ & \\
KEP3 & Pimpinan saya berusaha mencapai tujuan kolektif untuk memenuhi misi & \\
KEP4 & Pimpinan saya menyajikan tantangan dan proyek baru \\
KEP5 & Pimpinan saya percaya pada kemampuan pegawai/karyawan dalam menghadapi & \\
& hambatan & Law et al. \\
Basic need satisfaction (BNS) & $(2004)$ \\
BNS1 & Saya merasa dapat membuat banyak masukan dalam memutuskan bagaimana & \\
& pekerjaan saya selesai & \\
BNS2 & Saya memiliki peluang bagus untuk memutuskan sendiri bagaimana caranya & \\
BNS3 & Saytang pekerjaan saya & \\
BNS4 & Hampir setiap hari saya merasakan pencapaian dari bekerja & \\
BNS5 & Saya sangat menyukai orang-orang yang bekerja dengan saya & \\
BNS6 & Saya merasa terhubung dengan orang-orang yang bekerja dengan saya & \\
Motivasi Intrinsik (MOT) & Lin \& Peng \\
MOT1 & Saya sangat menikmati pekerjaan sehari-hari saya & $(2010)$ \\
MOT2 & Pekerjaan saya sangat menyenangkan \\
MOT3 & Saya suka melakukan sebagian besar proses kerja saya & \\
\hline
\end{tabular}

Dalam kaca mata Sekaran \& Bougie (2016) kerangka teoritis adalah fondasi yang mendasari seluruh proyek penelitian. Dari kerangka teori tersebut dapat dirumuskan hipotesis yang dapat diuji untuk mengetahui valid tidaknya teori yang dirumuskan. Kemudian selanjutnya akan diukur dengan analisis statistik yang sesuai. Mengacu pada teori dan penelitian sebelumnya, maka penulis membangun model penelitian sebagai mana disebutkan pada Gambar 1. 
4030 Quo Vadis Motivasi Intrinsik Pegawai: Peran Strategis Kepemimpinan Transformasional dan Kepuasan Kerja - Muhamad Agung Ali Fikri, Masduki Asbari, Dhaniel Hutagalung, Lala Hucadinota Ainul Amri, Dewiana Novitasari

DOI: https://doi.org/10.31004/edukatif.v3i6.1397

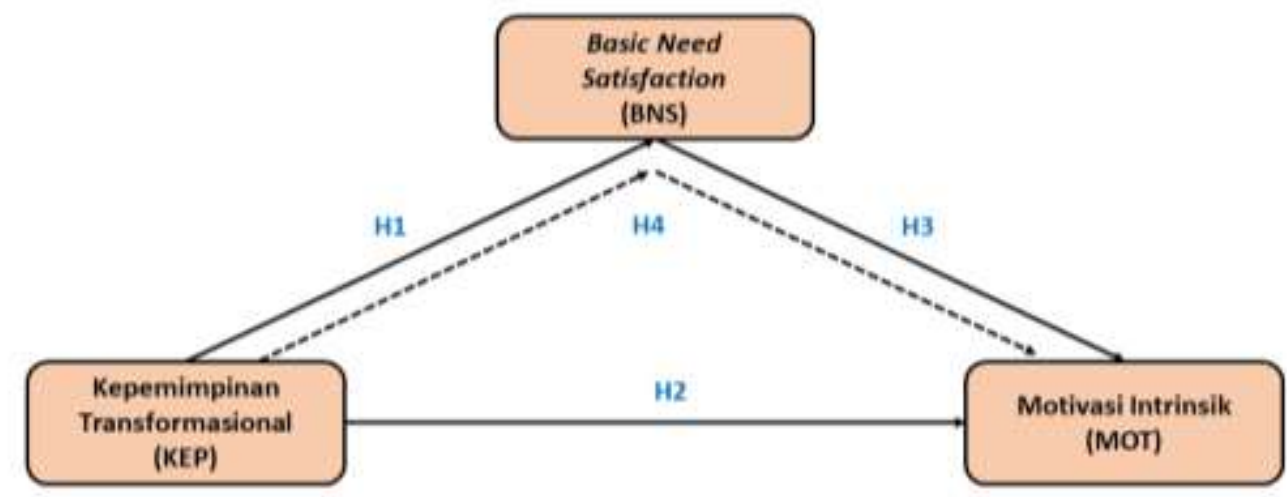

Gambar 1. Model Konseptual Penelitian

Berdasarkan penjelasan di atas, studi ini membangun hipotesis berikut ini:

Hipotesis 1 (H1): Kepemimpinan transformasional berpengaruh signifikan terhadap basic need satisfaction. Hipotesis 2 (H2): Kepemimpinan transformasional berpengaruh signifikan terhadap motivasi intrinsik.

Hipotesis 3 (H3): Basic need satisfaction berpengaruh signifikan terhadap motivasi intrinsik.

Hipotesis 4 (H4): Basic need satisfaction memediasi hubungan antara kepemimpinan transformasional dan motivasi intrinsik.

\section{HASIL DAN PEMBAHASAN}

\section{Deskripsi Sampel}

Total ada 109 karyawan yang berpartisipasi. Responden memiliki kelompok umur yang berbedabeda, berkisar antara di bawah usia 29 tahun (25.61\%), 30-49 tahun (56.33\%), dan lebih dari usia 50 tahun $(18.06 \%)$. Masa kerja mereka juga beragam, $32.97 \%$ di antaranya di bawah 5 tahun, $53.97 \%$ sudah bekerja antara 5-10 tahun, dan 13.06\% sisanya telah bekerja lebih dari 10 tahun. Pendidikan tertinggi responden adalah mayoritas setingkat SLTA (54.96\%), kemudian Peneliti (25.02\%) dan Diploma (D1/D2/D3) $(20.02 \%)$.

\section{Hasil Uji Validitas dan Reliabilitas Indikator Penelitian}

Tahap pengujian model pengukuran meliputi pengujian validitas konvergen, validitas diskriminan. Sementara untuk menguji reliabilitas konstruk digunakan nilai cronbach's alpha dan composite reliability. Hasil analisis PLS dapat digunakan untuk menguji hipotesis penelitian jika seluruh indikator dalam model PLS telah memenuhi syarat validitas konvergen, validitas deskriminan dan uji reliabilitas (Purwanto et al., 2020; Purwanto, Asbari, \& Santoso, 2021b, 2021a; Purwanto, Asbari, Santoso, et al., 2019, 2021).

\section{Pengujian Validitas Konvergen}

Uji validitas konvergen dilakukan dengan melihat nilai loading factor masing-masing indikator terhadap konstruknya. Pada sebagian besar referensi, bobot faktor sebesar 0.7 atau lebih dianggap memiliki validasi yang cukup kuat untuk menjelaskan konstruk laten (Chin, 1998; Ghozali, 2014; Hair et al., 2010). Pada penelitian ini batas minimal besarnya loading factor yang diterima adalah 0.7, dan dengan syarat nilai AVE setiap konstruk > 0.5 (Ghozali, 2014). Setelah melalui pengolahan SmartPLS 3.0, hasil memperlihatkan bahwa seluruh indikator telah memiliki nilai loading factor di atas 0.7 dan nilai AVE di atas 0.5. Model fit atau valid dari penelitian ini dapat dilihat pada Gambar 2. Jadi dengan demikian, validitas konvergen dari model penelitian ini sudah memenuhi syarat. Nilai loadings, cronbach's alpha, composite reliability dan AVE setiap konstruk selengkapnya dapat dilihat Tabel 2. 
4031 Quo Vadis Motivasi Intrinsik Pegawai: Peran Strategis Kepemimpinan Transformasional dan Kepuasan Kerja - Muhamad Agung Ali Fikri, Masduki Asbari, Dhaniel Hutagalung, Lala Hucadinota Ainul Amri, Dewiana Novitasari

DOI: https://doi.org/10.31004/edukatif.v3i6.1397

\section{Pengujian Validitas Deskriminan}

Discriminant validity dilakukan untuk memastikan bahwa setiap konsep dari masing-masing variabel laten berbeda dengan variabel laten lainnya. Model mempunyai discriminant validity yang baik jika nilai kuadrat AVE masing-masing konstruk eksogen (nilai pada diagonal) melebihi korelasi antara konstruk tersebut dengan konstruk lainnya (nilai di bawah diagonal) (Ghozali, 2014). Hasil pengujian discriminant validity adalah dengan menggunakan nilai kuadrat AVE, yakni dengan melihat Fornell-Larcker Criterion Value diperoleh sebagaimana ditunjukkan pada Tabel 3. Hasil uji validitas deskriminan pada tabel 3 di atas menunjukkan bahwa seluruh konstruk telah memiliki nilai akar kuadrat AVE di atas nilai korelasi dengan konstruk laten lainnya (melalui kriteria Fornell-Larcker), sehingga dapat disimpulkan bahwa model telah memenuhi validitas deskriminan (Fornell \& Larcker, 1981).

Selanjutnya dilakukan evaluasi collinearity untuk mengetahui ada tidaknya masalah collinearity pada model. Untuk menemukan collinearity tersebut, diperlukan statistik collinearity VIF dari setiap konstruk. Jika VIF lebih dari 5, maka model memiliki collinearity (Hair et al., 2014). Seperti yang ditunjukkan pada Tabel 4, semua skor VIF kurang dari 5, yakni hasil dari model struktural collinearity mengungkapkan nilai VIF di bawah 2. Hal ini menunjukkan bahwa model penelitian ini tidak ada masalah multikolinearitas.

\section{Pengujian Reliabilitas Konstruk}

Reliabilitas konstruk dapat dinilai dari nilai cronbach's alpha dan composite reliability dari masingmasing konstruk. Nilai composite reliability dan cronbach's alpha yang disarankan adalah lebih dari 0.7 (Ghozali, 2014). Hasil uji reliabilitas pada tabel 2 di atas menunjukkan bahwa seluruh konstruk telah memiliki nilai composite reliability dan cronbach's alpha lebih besar dari 0.7 (> 0.7). Kesimpulannya, seluruh konstruk telah memenuhi reliabilitas yang dipersyaratkan.

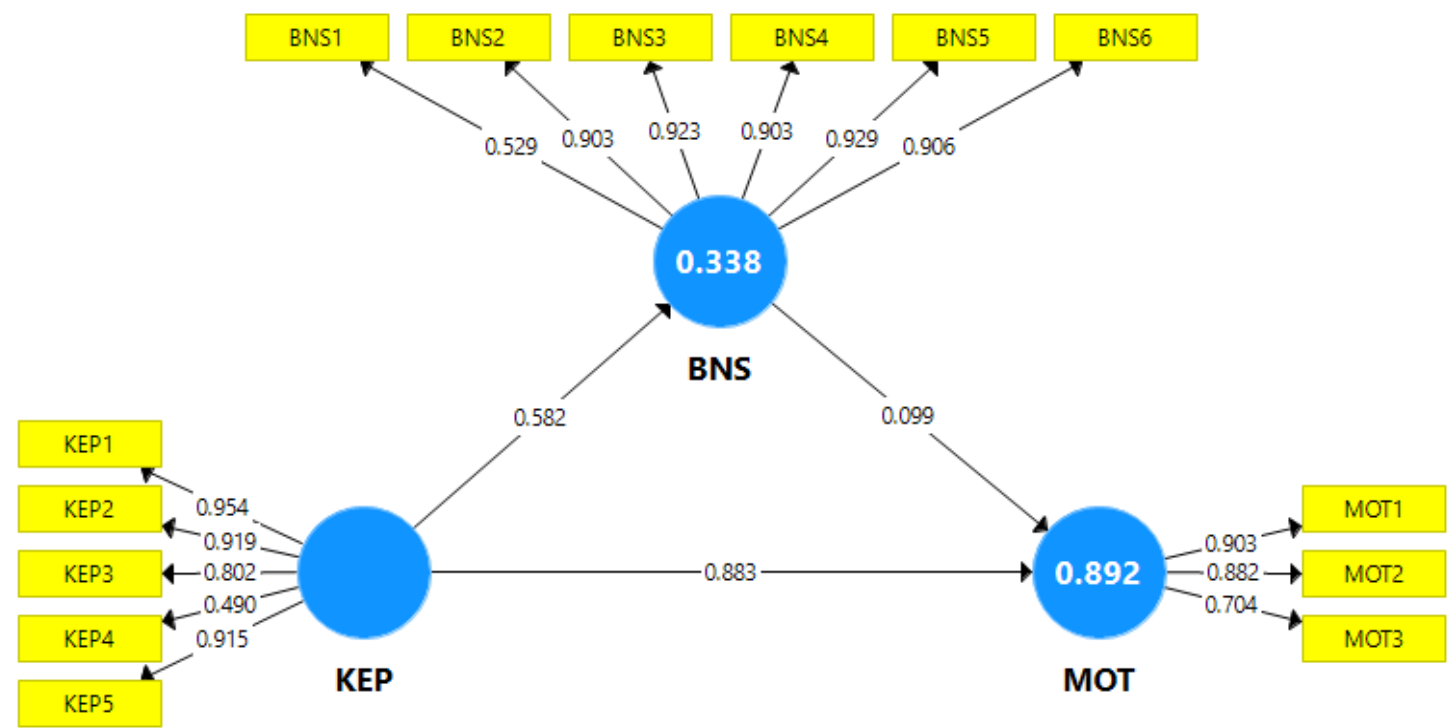

Gambar 2. Model Penelitian Valid

Sumber: Hasil Pengolahan SmartPLS 3.0 (2021)

Tabel 2

Items Loadings, Cronbach's Alpha, Composite Reliability, and Average Variance Extracted (AVE)

\begin{tabular}{|c|c|c|c|c|c|c|}
\hline Variables & Items & Loadings & $\begin{array}{l}\text { Cronbach's } \\
\text { Alpha }\end{array}$ & Rho-A & $\begin{array}{l}\text { Composite } \\
\text { Reliability }\end{array}$ & AVE \\
\hline $\begin{array}{l}\text { Kepemimpinan Transformasional } \\
\text { (KEP) }\end{array}$ & KEP1 & 0,954 & 0,880 & 0,925 & 0,916 & 0,695 \\
\hline
\end{tabular}


4032 Quo Vadis Motivasi Intrinsik Pegawai: Peran Strategis Kepemimpinan Transformasional dan Kepuasan Kerja - Muhamad Agung Ali Fikri, Masduki Asbari, Dhaniel Hutagalung, Lala Hucadinota Ainul Amri, Dewiana Novitasari

DOI: https://doi.org/10.31004/edukatif.v3i6.1397

\begin{tabular}{|c|c|c|c|c|c|c|}
\hline & $\begin{array}{l}\text { KEP2 } \\
\text { KEP3 } \\
\text { KEP4 } \\
\text { KEP5 }\end{array}$ & $\begin{array}{l}0,919 \\
0,802 \\
0,490 \\
0,915\end{array}$ & & & & \\
\hline Basic need satisfaction (BNS) & $\begin{array}{l}\text { BNS1 } \\
\text { BNS2 } \\
\text { BNS3 } \\
\text { BNS4 } \\
\text { BNS5 } \\
\text { BNS6 }\end{array}$ & $\begin{array}{l}0,529 \\
0,903 \\
0,923 \\
0,903 \\
0,929 \\
0,906\end{array}$ & 0,923 & 0,936 & 0,943 & 0,741 \\
\hline Motivasi Intrinsik (MOT) & $\begin{array}{l}\text { MOT1 } \\
\text { MOT2 } \\
\text { MOT3 }\end{array}$ & $\begin{array}{l}0,903 \\
0,882 \\
0,704\end{array}$ & 0,784 & 0,849 & 0,872 & 0,696 \\
\hline
\end{tabular}

Sumber: Hasil Pengolahan SmartPLS 3.0 (2021)

Tabel 3

Discriminant Validity

\begin{tabular}{lccc}
\hline Variables & BNS & KEP & MOT \\
\hline BNS & 0,861 & & \\
KEP & 0,582 & 0,834 & \\
MOT & 0,613 & 0,941 & 0,834 \\
\hline
\end{tabular}

Sumber: Hasil Pengolahan SmartPLS 3.0 (2021)

Tabel 4

Collinearity (VIF)

\begin{tabular}{lccc}
\hline Variables & BNS & KEP & MOT \\
\hline BNS & & & 1,511 \\
KEP & 1,000 & & 1,511 \\
MOT & & \\
Sumber: Hasil Pengolahan SmartPLS 3.0 (2021) & &
\end{tabular}

Tabel 5

Nilai $R$ Square

\begin{tabular}{lcc}
\hline Variables & R Square & $\begin{array}{c}\text { R Square } \\
\text { Adjusted }\end{array}$ \\
\hline BNS & 0,338 & 0,332 \\
MOT & 0,892 & 0,890
\end{tabular}

Sumber: Hasil Pengolahan SmartPLS 3.0 (2021)

Tabel 6

Hypotheses Testing

\begin{tabular}{|c|c|c|c|c|c|c|c|}
\hline Hypotheses & Relationship & Beta & M & SE & T Statistics & P-Values & Decision \\
\hline $\mathrm{H} 1$ & KEP -> BNS & 0,582 & 0,585 & 0,049 & 11,932 & 0,000 & Didukung \\
\hline $\mathrm{H} 2$ & KEP -> MOT & 0,883 & 0,885 & 0,022 & 40 & 0,000 & Didukung \\
\hline $\mathrm{H} 3$ & BNS -> MOT & 0,099 & 0,096 & 0,033 & 2,992 & 0,003 & Didukung \\
\hline $\mathrm{H} 4$ & KEP $>$ BNS $>>$ MOT & 0,058 & 0,056 & 0,020 & 2,858 & 0,004 & Didukung \\
\hline
\end{tabular}

Sumber: Hasil Pengolahan SmartPLS 3.0 (2021) 
4033 Quo Vadis Motivasi Intrinsik Pegawai: Peran Strategis Kepemimpinan Transformasional dan Kepuasan Kerja - Muhamad Agung Ali Fikri, Masduki Asbari, Dhaniel Hutagalung, Lala Hucadinota Ainul Amri, Dewiana Novitasari

DOI: https://doi.org/10.31004/edukatif.v3i6.1397

\section{Pengujian Hipotesis}

Pengujian hipotesis dalam PLS disebut juga sebagai uji inner model. Uji ini meliputi uji signifikansi pengaruh langsung dan tidak langsung serta pengukuran besarnya pengaruh variabel eksogen terhadap variabel endogen. Untuk mengetahui pengaruh kepemimpinan transformasional terhadap motivasi intrinsic pegawai melalui basic need satisfaction sebagai variable mediasi dibutuhkan uji pengaruh langsung dan tidak langsung. Uji pengaruh dilakukan dengan menggunakan uji t-statistik dalam model analisis partial least squared (PLS) dengan menggunakan bantuan software SmartPLS 3.0. Dengan teknik boothstrapping, diperoleh nilai $R$ Square dan nilai uji signifikansi sebagaimana Tabel 5 dan Tabel 6 .

Berdasarkan Tabel 5 di atas, nilai $R$ Square basic need satisfaction (BNS) sebesar 0.338 yang berarti bahwa variable basic need satisfaction (BNS) mampu dijelaskan oleh variabel kepemimpinan transformasional (KEP) sebesar 33.8\%, sedangkan sisanya sebesar 66.2\% dijelaskan oleh variabel lain yang tidak dibahas dalam penelitian ini. Sementara itu, nilai $R$ Square motivasi intrinsik karyawan (MOT) sebesar 0.892 yang berarti bahwa variabel motivasi intrinsik karyawan (MOT) mampu dijelaskan oleh variabel kepemimpinan transformasional (KEP) dan variabel basic need satisfaction (BNS) sebesar 89,2\%, sedangkan sisanya sebesar 10,2\% dijelaskan oleh variabel lain yang tidak dibahas dalam penelitian ini. Artinya bahwa substansi pengaruh dalam model hubungan pada model penelitian ini adalah terbilang sangat kuat (Chin, 1998). Sedangkan Tabel 6 menampilkan t-statistics dan p-values yang menunjukkan pengaruh antar variable penelitian yang telah disebutkan

Peneliti menyajikan hasil untuk jalur langsung dari transformasional kepemimpinan untuk motivasi intrinsic (H2). Kedua, peneliti lanjutkan ke masing-masing syarat mediasi; yaitu, jalan dari transformasional kepemimpinan untuk basic need satisfaction (H1) dan dari basic need satisfaction terhadap motivasi intrinsic (H3). Akhirnya, peneliti menguji signifikansi bersama dari hubungan tidak langsung tersebut (H4). Dari hasil pengujian yang dipaparkan pada Tabel 6 , ditemukan fakta bahwa seluruh hipotesis diterima $(\mathrm{H} 1, \mathrm{H} 2, \mathrm{H} 3, \mathrm{H} 4$ diterima/didukung). Peneliti mencatat bahwa data peneliti menemukan fakta dukungan parsial untuk jalur langsung dari kepemimpinan transformasional ke basic need satisfaction (H1) dan motivasi intrinsic (H3). Hal ini berarti persepsi pegawai/karyawan tentang perilaku pimpinan ransformasional kepemimpinan sangat positif dan signifikan secara statistic terhadap basic need satisfaction dan motivasi intrinsic. Hasil ini menunjukkan bahwa pegawai/karyawan mengekspresikan kesenangan dan kegembiraan yang lebih besar dalam pekerjaan ketika pimpinan mengandalkan kepemimpinan transformasional ke tingkat yang lebih besar. Untuk menilai hipotesis, peneliti menguji apakah transformasional kepemimpinan berhubungan langsung dengan motivasi intrinsic, dan secara tidak langsung melalui basic need satisfaction. Di sini, peneliti menemukan fakta hubungan pengaruh yang positif dan signifikan.

Hasil ini menguatkan gagasan tersebut dalam SDT bahwa kepuasan kerja sangat penting untuk meningkatkan motivasi intrinsic dalam setiap aktivitas pekerjaan (Fayzhall et al., 2020; Hutagalung et al., 2020; Jumiran et al., 2020; Novitasari, Asbari, Purwanto, et al., 2020; Novitasari, Asbari, \& Sasono, 2021; Nuryanti et al., 2020; Sutardi et al., 2020; Yuwono, Novitasari, Asbari, et al., 2020; Yuwono, Novitasari, Hutagalung, et al., 2020), sedangkan kepuasan kerja sangat berkaitan dengan pengaruh positif dari kepemimpinan transformasional (Choi et al., 2016; Fayzhall et al., 2020; Weller et al., 2019). Hasil kerja penelitian ini didukung oleh para peneliti sebelumnya yang teelah disebutkan di atas. Jelasnya, peneliti mengientifikasi bahwa kepemimpinan transformasional mampu meningkatkan kepuasan kerja dan motivasi intrinsic.

Studi ini memiliki beberapa keterbatasan pada beberapa hal. Pertama, kepemimpinan transformasional, basic need satisfaction dan motivasi intrinsic semuanya diukur pada satu titik waktu, dan ini membuatnya sulit untuk ditentukan dengan jelas urutan temporal variabel secara empiris. Meskipun SDT secara eksplisit berpendapat sesuai dengan urutan kausal yang diusulkan dalam studi ini, yakni kepuasan dasar dalam bekerja 
4034 Quo Vadis Motivasi Intrinsik Pegawai: Peran Strategis Kepemimpinan Transformasional dan Kepuasan Kerja - Muhamad Agung Ali Fikri, Masduki Asbari, Dhaniel Hutagalung, Lala Hucadinota Ainul Amri, Dewiana Novitasari

DOI: https://doi.org/10.31004/edukatif.v3i6.1397

yang meningkat akan meningkatkan motivasi intrinsic karyawan (Bidee et al., 2017; Goldman et al., 2017; Rezvani et al., 2017). Kedua, sampel hanya terdiri dari pegawai/karyawan industry manufaktur di Jawa Barat yang pemimpinnya (pimpinan) secara sukarela berpartisipasi dalam penelitian ini. Ini bisa menjadi masalah dalam hal generalisasi ke populasi pegawai/karyawan yang pemimpinnya tidak sukarela. Ketiga, populasi penelitian ini adalah karyawan industry manufaktur, yang bisa jadi hasilnya berbeda jika penelitian ini dilakukan pada populasi industry lainnya, seperti ritel dan industry jasa yang sejenisnya.

\section{KESIMPULAN}

Studi ini berangkat untuk memeriksa apakah kepemimpinan transformasional berhubungan dengan motivasi intrinsic, baik secara langsung dan tidak langsung melalui basic need satisfaction di industry manufaktur. Analisis empiris peneliti mengungkapkan beberapa hasil menarik: Pertama, kepemimpinan transformasional berpengaruh signifikan dan positif terhadap basic need satisfaction. Kedua, kepemimpinan transformasional berpengaruh signifikan dan positif terhadap motivasi intrinsic karyawan/pegawai. Ketiga, basic need satisfaction berpengaruh signifikan dan positif terhadap motivasi intrinsic karyawan/pegawai. Keempat, basic need satisfaction memediasi pengaruh kepemimpinan transformasional terhadap motivasi intrinsic karyawan/pegawai.

\section{Implikasi}

Seperti yang digarisbawahi oleh penelitian ini bahwa temuan ini tidak hanya menguatkan studi yang ada tentang kepemimpinan transformasional sebagai anteseden penting bagi motivasi (Al-Mansoori \& Koç, 2019; Jensen \& Bro, 2018; Løvaas et al., 2020; Mahmood et al., 2019; Masood \& Afsar, 2017) dan bagi kepuasan kerja (Aldholay et al., 2018; Silitonga et al., 2020; Singgih et al., 2020), tetapi juga menyoroti psikologis mekanisme yang mendasari hubungan ini di dunia manufaktur. Jika manajer bertujuan untuk merangsang motivasi berdasarkan kegembiraan yang melekat dalam pekerjaan, maka tampaknya sangat relevan untuk fokus pada memenuhi kebutuhan kepuasan kerja, misalnya, untuk meningkatkan motivasi intrinsik karyawan dalam menyelesaikan suatu project, manajemen perlu menghindari micro-management tetapi justru mengungkapkan kepercayaan pada karyawan tersebut.

Akhirnya, penelitian ini menarik garis untuk penelitian tentang bagaimana manajer dapat memastikan bahwa karyawan mempersepsikan upaya teknis manajemen, seperti hadiah uang atau sistem perintah, sebagai mendukung pekerjaan mereka. Teori motivasi crowding (Putra et al., 2017) berpendapat bahwa persepsi insentif moneter (terkait dengan kepemimpinan transaksional) tergantung pada sejauh mana mana hal tersebut ini memuaskan psikologis dasar karyawan terhadap kebutuhan akan otonomi, kompetensi, dan kemelekatan terhadap organisasi. Dalam temuan penelitian ini, para pemimpin transformasional dapat menggunakan visi untuk mendukung persepsi alat manajerial lainnya, seperti sistem insentif, karena visi menggambarkan betapa tujuan personal tertentu berkontribusi pada tujuan organisasi dan kontribusi sosial yang lebih luas. Hal ini senada dengan para ahli lainnya yang menyarankan efek tambahan dari transformasional dan kepemimpinan transaksional (Asbari, Fayzhall, et al., 2020; Asbari \& Novitasari, 2021; Novitasari, Asbari, \& Purwanto, 2020; Novitasari, Haque, Supriatna, et al., 2021b), meskipun sangat sedikit penelitian yang menyelidiki apakah kombinasi kepemimpinan transformasional dan transaksional memang merangsang tingkat yang lebih tinggi dari motivasi intrinsik. Oleh karena itu, para peneliti sangat didorong untuk mengeksplorasi hal tersebut dalam studi di masa depan.

\section{DAFTAR PUSTAKA}

Admiral, Chidir, G., Asbari, M., Supriatna, H., \& Novitasari, D. (2021). Linking Employee Coaching, Team Commitment and Performance: Evidence from Indonesian MSMEs. International Journal of Social and Management Studies (IJOSMAS), 02(04), 22-34. 
4035 Quo Vadis Motivasi Intrinsik Pegawai: Peran Strategis Kepemimpinan Transformasional dan Kepuasan Kerja - Muhamad Agung Ali Fikri, Masduki Asbari, Dhaniel Hutagalung, Lala Hucadinota Ainul Amri, Dewiana Novitasari

DOI: https://doi.org/10.31004/edukatif.v3i6.1397

https://www.ijosmas.org/index.php/ijosmas/article/view/48

Al-Ibrahim, A. (2014). Quality Management and Its Role in Improving Service Quality in Public Sector. Journal of Business and Management Sciences, 2(6), 123-147. https://doi.org/10.12691/jbms-2-6-1

Al-Mansoori, R. S., \& Koç, M. (2019). Transformational leadership, systems, and intrinsic motivation impacts on innovation in higher education institutes: Faculty perspectives in engineering colleges. Sustainability (Switzerland), 11(15). https://doi.org/10.3390/su11154072

Aldholay, A. H., Isaac, O., Abdullah, Z., \& Ramayah, T. (2018). The role of transformational leadership as a mediating variable in DeLone and McLean information system success model: The context of online learning usage in Yemen. Telematics and Informatics, 35(5), 1421-1437.

https://doi.org/10.1016/j.tele.2018.03.012

Anggraeni, A., Hasna, S., Novitasari, D., \& Asbari, M. (2020). Pengaruh Pelatihan Kerja dan Motivasi Kerja Terhadap Prestasi Karyawan pada PT. Agrindo Maju Lestari. JUBISMA, 2(1), 1-18.

http://jubisma.ipem.ac.id/index.php/JUBISMA/article/view/32

Asbari, M. (2020). Is Transformational Leadership Suitable for Future Organizational Needs? International Journal of Sociology, Policy and Law (Ijospl), 01(01), 51-55.

https://ijospl.org/index.php/ijospl/article/view/17

Asbari, M., Fayzhall, M., Goestjahjanti, F. S., Winanti, Yuwono, T., Hutagalung, D., Basuki, S., Maesaroh, S., Mustofa, Chidir, G., Yani, A., \& Purwanto, A. (2020). Peran Kepemimpinan Transformasional Dan Organisasi Pembelajaran Terhadap Kapasitas Inovasi Sekolah. EduPsyCouns: Journal of Education, Psychology and Counseling, 2(1), 6724-6748.

https://ummaspul.e-journal.id/Edupsycouns/article/view/421

Asbari, M., \& Novitasari, D. (2020). The Role of Readiness for Change on Part-Timer Employee Performance: Analysis of Transformational Leadership Practice in Convection Industry. Journal of Communication Education (JOCE), 14(02). http://jurnal.ipem.ac.id/index.php/joce-ip/article/view/220

Asbari, M., \& Novitasari, D. (2021). Pengaruh Authentic Leadership terhadap Mentalitas Siap Berubah dan Kinerja Pegawai Paruh Waktu. Business Management Journal, 17(1), 73-88.

Asbari, M., Purba, J. T., Hariandja, E. S., \& Sudibjo, N. (2021a). From Leadership to Innovation: Managing Employee Creativity. Jurnal Manajemen Strategi Dan Aplikasi Bisnis, 4(1), 143-154. https://doi.org/https://doi.org/10.36407/jmsab.v4i1.287

Asbari, M., Purba, J. T., Hariandja, E. S., \& Sudibjo, N. (2021b). Membangun Kesiapan Berubah dan Kinerja Karyawan: Kepemimpinan Transformasional versus Transaksional. Jurnal Ilmiah Manajemen Dan Bisnis, 22(1), 54-71.

Asbari, M., Purwanto, A., \& Santoso, P. B. (2019). Influence of Leadership, Motivation, Competence, Commitment and Culture on ISO 9001:2015 Performance in Packaging Industry. Scholars Journal of Economics, Business and Management, 6(12), 577-582.

https://doi.org/10.36347/sjebm.2019.v06i12.005

Asbari, M., Santoso, P. B., \& Prasetya, A. B. (2020). Elitical and Antidemocratic Transformational Leadership Critics: Is It Still Relevant? (A Literature Study). International Journal of Sociology, Policy and Law (Ijospl), 01(01), 11-16. https://doi.org/https://doi.org/10.8888/ijospl.v1i1.10

Bidee, J., Vantilborgh, T., Pepermans, R., Willems, J., Jegers, M., \& Hofmans, J. (2017). Daily motivation of volunteers in healthcare organizations: relating team inclusion and intrinsic motivation using selfdetermination theory. European Journal of Work and Organizational Psychology, 26(3), 325-336. https://doi.org/10.1080/1359432X.2016.1277206

Bogler, R. (2001). The influence of leadership style on teacher job satisfaction. Educational Administration Quarterly, 37(5), 662-683. https://doi.org/10.1177/00131610121969460 
4036 Quo Vadis Motivasi Intrinsik Pegawai: Peran Strategis Kepemimpinan Transformasional dan Kepuasan Kerja - Muhamad Agung Ali Fikri, Masduki Asbari, Dhaniel Hutagalung, Lala Hucadinota Ainul Amri, Dewiana Novitasari

DOI: https://doi.org/10.31004/edukatif.v3i6.1397

Chidir, G., Kumoro, D. F. C., Johan, M., Asbari, M., \& Novitasari, D. (2021). Learning dan Coaching: Analisis Anteseden Manajemen Kinerja Dosen. Cetta: Jurnal Ilmu Pendidikan, 4(2), 293-315.

Chin, W. (1998). The Partial Least Squares Approach to Structural Equation Modeling (E. Modern Methods for Business Research, In: G. A. Marcoulides (ed.)). Lawrence Erlbaum Associates Publisher.

Choi, S. L., Goh, C. F., Adam, M. B. H., \& Tan, O. K. (2016). Transformational leadership, empowerment, and job satisfaction: The mediating role of employee empowerment. Human Resources for Health, 14(1), 1-14. https://doi.org/10.1186/s12960-016-0171-2

Deci, E. L., Olafsen, A. H., \& Ryan, R. M. (2017). Self-Determination Theory in Work Organizations: The State of a Science. Annual Review of Organizational Psychology and Organizational Behavior, 4(1), 19-43. https://doi.org/10.1146/annurev-orgpsych-032516-113108

Fayzhall, M., Asbari, M., Purwanto, A., Goestjahjanti, F. S., Yuwono, T., Radita, F. R., Yulia, Y., Cahyono, Y., \& Suryani, P. (2020). Transformational versus Transactional Leadership: Manakah yang Mempengaruhi Kepuasan Kerja Guru? EduPsyCouns: Journal of Education, Psychology and Counseling, 2(1), 256-275. https://ummaspul.e-journal.id/Edupsycouns/article/view/463

Fornell, C., \& Larcker, D. F. (1981). Evaluating Structural Equation Models with Unobservable Variables and Measurement Error. Journal of Marketing Research, 18(1), 39. https://doi.org/10.2307/3151312

Gagné, M., \& Deci, E. L. (2005). Self-determination theory and work motivation. Journal of Organizational Behavior, 26(4), 331-362.

Ghozali, I. (2014). Structural Equation Modeling, Metode Alternatif dengan Partial Least Square (PLS) (4th ed.). Badan Penerbit Universitas Diponegoro.

Goldman, Z. W., Goodboy, A. K., \& Weber, K. (2017). College Students' Psychological Needs and Intrinsic Motivation to Learn: An Examination of Self-Determination Theory. Communication Quarterly, 65(2), 167-191. https://doi.org/10.1080/01463373.2016.1215338

Hair, J. F., Black, W. C., Babin, B. J., \& Anderson, R. E. (2010). Multivariate Data Analysis (7th ed.). Pearson Prentice Hall.

Hutagalung, D., Admiral, Nuryanti, Y., Asbari, M., \& Novitasari, D. (2021). Managing Tacit Knowledge Sharing: From Charismatic Leadership to Psychological Safety Climate. Inovbiz: Jurnal Inovasi Bisnis, 9(1), 108-119. https://doi.org/10.35314/inovbiz.v9i1.1888

Hutagalung, D., Asbari, M., Fayzhall, M., Ariyanto, E., Agistiawati, E., Sudiyono, R. N., Waruwu, H., Goestjahjanti, F. S., Winanti, \& Yuwono, T. (2020). Peran Religiusitas, Kepemimpinan Transformasional, Kepuasan Kerja dan Mediasi Organizational Citizenship Behavior terhadap Kinerja Guru. EduPsyCouns: Journal of Education, Psychology and Counseling, 2(1), 311-326. https://ummaspul.e-journal.id/Edupsycouns/article/view/483

Jensen, U. T., \& Bro, L. L. (2018). How Transformational Leadership Supports Intrinsic Motivation and Public Service Motivation: The Mediating Role of Basic need satisfaction. American Review of Public Administration, 48(6), 535-549. https://doi.org/10.1177/0275074017699470

Johan, M., Budiadnyana, G. N., Admiral, Asbari, M., \& Novitasari, D. (2021a). Kepemimpinan Karismatik dalam Perspektif Karyawan UMKM: dari Motivasi Intrinsik hingga Tacit Knowledge Sharing. Edumaspul: Jurnal Pendidikan, 5(1), 598-613.

Johan, M., Budiadnyana, G. N., Admiral, Asbari, M., \& Novitasari, D. (2021b). Kepemimpinan Karismatik dalam Perspektif Karyawan UMKM: dari Motivasi Intrinsik hingga Tacit Knowledge Sharing. Edumaspul: Jurnal Pendidikan, 5(1), 598-613. https://ummaspul.e-journal.id/maspuljr/article/view/1303

Jumiran, Novitasari, D., Nugroho, Y. A., Sutardi, D., Sasono, I., \& Asbari, M. (2020). Pengaruh Dimensi Kepemimpinan Transformasional terhadap Kepuasan Kerja dan Komitmen Organisasional: Studi Kasus 
4037 Quo Vadis Motivasi Intrinsik Pegawai: Peran Strategis Kepemimpinan Transformasional dan Kepuasan Kerja - Muhamad Agung Ali Fikri, Masduki Asbari, Dhaniel Hutagalung, Lala Hucadinota Ainul Amri, Dewiana Novitasari

DOI: https://doi.org/10.31004/edukatif.v3i6.1397

pada Dosen Perguruan Tinggi Swasta. EduPsyCouns: Journal of Education, Psychology and Counseling, 2(1), 600-621. https://ummaspul.e-journal.id/Edupsycouns/article/view/555

Law, K. S., Wong, C.-S., \& Song, L. J. (2004). The construct and criterion validity of emotional intelligence and its potential utility for management studies. Journal of Applied Psychology, 89(3), 483.

Lin, C., \& Peng, T. (2010). From organizational citizenship behaviour to team performance: The mediation of group cohesion and collective efficacy. Management and Organization Review, 6(1), 55-75.

Løvaas, B. J., Jungert, T., Van den Broeck, A., \& Haug, H. (2020). Does managers' motivation matter? Exploring the associations between motivation, transformational leadership, and innovation in a religious organization. Nonprofit Management and Leadership, June 2018, 1-21.

https://doi.org/10.1002/nml.21405

Maesaroh, S., Asbari, M., Hutagalung, D., Agistiawati, E., Basuki, S., Radita, F. R., Nurasiah, Yulia, Y., Singgih, E., \& Chidir, G. (2020). Pengaruh Religiusitas dan Kepemimpinan Transformasional terhadap Kinerja Guru melalui Mediasi Organizational Citizenship Behavior. EduPsyCouns: Journal of Education, Psychology and Counseling, 2(1), 276-290.

https://ummaspul.e-journal.id/Edupsycouns/article/view/473

Mahmood, M., Uddin, M. A., \& Fan, L. (2019). The influence of transformational leadership on employees' creative process engagement: A multi-level analysis. Management Decision, 57(3), 741-764.

https://doi.org/10.1108/MD-07-2017-0707

Manganelli, L., Thibault-Landry, A., Forest, J., \& Carpentier, J. (2018). Self-Determination Theory Can Help You Generate Performance and Well-Being in the Workplace: A Review of the Literature. Advances in Developing Human Resources, 20(2), 227-240. https://doi.org/10.1177/1523422318757210

Masood, M., \& Afsar, B. (2017). Transformational leadership and innovative work behavior among nursing staff. Nursing Inquiry, 24(4). https://doi.org/10.1111/nin.12188

Nadeak, M., Widodo, A., Asbari, M., Novitasari, D., \& Purwanto, A. (2021). Understanding the Links between Coaching, OCB, and Individual Performance among MSME Employees. International Journal of Social and Management Studies, 2(04), 65-80.

Novitasari, D., Asbari, M., \& Purwanto, A. (2020). Maximizing Employee Performance: An Analysis of Organizational and Individual Factors. International Journal of Social and Management Studies, 1(1), 95-104.

Novitasari, D., Asbari, M., Purwanto, A., Iskandar, J., Sutardi, D., Silitonga, N., \& Putra, A. S. (2020). Peran Social Support terhadap Work Conflict, Kepuasan dan Kinerja. Jurnal Penelitian Ilmu Manajemen (JPIM), 5(2), 187-202. https://doi.org/http://dx.doi.org/10.30736\%2Fjpim.v5i2.350

Novitasari, D., Asbari, M., Putra, F., Kumoro, D. F. C., \& Fikri, M. A. A. (2021). Tacit Knowledge Sharing di Sekolah Islam: Analisis Kepemimpinan dan Iklim Keamanan Psikologis. Cetta: Jurnal Ilmu Pendidikan, 4(2), 138-162. http://jayapanguspress.penerbit.org/index.php/cetta/article/view/1287

Novitasari, D., Asbari, M., \& Sasono, I. (2021). Pengaruh Religiusitas dan Kualitas Pelayanan terhadap Kepuasan Kerja. Jurnal Manajemen Strategi Dan Aplikasi Bisnis, 4(1), 117-130. https://doi.org/https://doi.org/10.36407/jmsab.v4i1.268

Novitasari, D., Goestjahjanti, F. S., \& Asbari, M. (2020). The Role of Readiness to Change between Transformational Leadership and Performance: Evidence from a Hospital during Covid-19 Pandemic. APMBA (Asia Pacific Management and Business Application), 9(1), 37-56. https://doi.org/10.21776/ub.apmba.2020.009.01.4

Novitasari, D., Haque, M. G., Supriatna, H., Asbari, M., \& Purwanto, A. (2021a). Understanding the Links between Charismatic Leadership, Intrinsic Motivation and Tacit Knowledge Sharing among MSME Employees. International Journal of Social and Management Studies (IJOSMAS), 02(03), 1-13. 
4038 Quo Vadis Motivasi Intrinsik Pegawai: Peran Strategis Kepemimpinan Transformasional dan Kepuasan Kerja - Muhamad Agung Ali Fikri, Masduki Asbari, Dhaniel Hutagalung, Lala Hucadinota Ainul Amri, Dewiana Novitasari

DOI: https://doi.org/10.31004/edukatif.v3i6.1397

https://www.ijosmas.org/index.php/ijosmas/article/view/29

Novitasari, D., Haque, M. G., Supriatna, H., Asbari, M., \& Purwanto, A. (2021b). Understanding the Links between Charismatic Leadership, Intrinsic Motivation and Tacit Knowledge Sharing among MSME Employees. International Journal of Social and Management Studies (IJOSMAS), 2(03), 1-13.

Novitasari, D., Supiana, N., Supriatna, H., Fikri, M. A. A., \& Asbari, M. (2021). The Role of Leadership on Innovation Performance: Transactional versus Transformational Style. JIMFE (Jurnal Ilmiah Manajemen Fakultas Ekonomi), 7(1), 27-36.

https://journal.unpak.ac.id/index.php/jimfe/article/view/2981

Nugroho, Y. A., Asbari, M., Purwanto, A., Basuki, S., Sudiyono, R. N., Fikri, M. A. A., Hulu, P., Mustofa, Chidir, G., Suroso, \& Xavir, Y. (2020). Transformational Leadership and Employees' Performance: the Mediating Role of Motivation and Work Environment. EduPsyCouns: Journal of Education, Psychology and Counseling, 2(1), 438-460.

https://ummaspul.e-journal.id/Edupsycouns/article/view/507

Nugroho, Y. A., Hutagalung, D., Asbari, M., Supriatna, H., \& Novitasari, D. (2021). Mempertahankan Kinerja Karyawan UMKM: Analisis Pengaruh Managerial Coaching dan Motivasi Intrinsik. Value: Jurnal Manajemen Dan Akuntansi, 16(2), 54-68.

Nuryanti, Y., Novitasari, D., Nugroho, Y. A., Fauji, A., Gazali, \& Asbari, M. (2020). Meningkatkan Komitmen Organisasional Dosen: Analisis Pengaruh Kepemimpinan Perguruan Tinggi dan Kepuasan Intrinsik \& Ekstrinsik Dosen. EduPsyCouns: Journal of Education, Psychology and Counseling, 2(1), 561-581. https://ummaspul.e-journal.id/Edupsycouns/article/view/551

Podsakoff, P. M., Mackenzie, S. B., Moorman, R. H., \& Fetter, R. (1990). Leader Behaviors and Their Effects on Followers' Trust in Leader, Satisfaction, and Citizenship Behaviors. Leadership Quarterly, 1(2), 107-142.

Pramono, T., Asbari, M., Supriatna, H., Nugroho, Y. A., \& Novitasari, D. (2021). Rahasia Inovasi Karyawan Wanita di Era Digital: Analisis Modal Psikologis dan Dukungan Kepemimpinan. Value: Jurnal Manajemen Dan Akuntansi, 16(2), 1-17.

Purwanto;, A., Asbari;, M., \& Santoso, P. B. (2019). Pengaruh Kompetensi, Motivasi, Kepemimpinan, Komitmen dan Budaya Kerja Sistem Manajemen Integrasi ISO 9001, ISO 14000 dan ISO 45001 pada Industri Otomotif. Jurnal Produktivitas, 6(2), 158-166.

http://openjurnal.unmuhpnk.ac.id/index.php/jp/article/view/1798

Purwanto, A., Asbari, M., \& Santoso, P. B. (2019). Influence of Transformational and Transactional Leadership Style toward Food Safety Management System ISO 22000:2018 Performance of Food Industry in Pati Central Java. Inovbiz: Jurnal Inovasi Bisnis, 7(2), 180-185. https://doi.org/10.35314/inovbiz.v7i2.1213

Purwanto, A., Asbari, M., \& Santoso, T. I. (2021a). Analisis Data Penelitian Manajemen Pendidikan: Perbandingan Hasil antara Amos, SmartPLS, WarpPLS, dan SPSS untuk Jumlah Sampel Kecil. International Journal of Social, Policy and Law (IJOSPL), 01(01), 111-122. https://ijospl.org/index.php/ijospl/article/view/64

Purwanto, A., Asbari, M., \& Santoso, T. I. (2021b). Education Management Research Data Analysis: Comparison of Results between Lisrel, Tetrad, GSCA, Amos, Smartpls, Warppls, And SPSS for Small Samples. Nidhomul Haq: Jurnal Manajemen Pendidikan Islam, 6(2), 382-399.

https://e-journal.ikhac.ac.id/index.php/nidhomulhaq/article/view/1575

Purwanto, A., Asbari, M., Santoso, T. I., Haque, M. G., \& Nurjaya. (2019). Marketing Research Quantitative Analysis for Large Sample: Comparing of Lisrel, Tetrad, GSCA, Amos, SmartPLS, WarpPLS, and SPSS. Jurnal Ilmiah Ilmu Administrasi Publik: Jurnal Pemikiran Dan Penelitian Administrasi Publik, 9(2), 355-372. https://ojs.unm.ac.id/iap/article/view/22803 
4039 Quo Vadis Motivasi Intrinsik Pegawai: Peran Strategis Kepemimpinan Transformasional dan Kepuasan Kerja - Muhamad Agung Ali Fikri, Masduki Asbari, Dhaniel Hutagalung, Lala Hucadinota Ainul Amri, Dewiana Novitasari

DOI: https://doi.org/10.31004/edukatif.v3i6.1397

Purwanto, A., Asbari, M., Santoso, T. I., Paramarta, V., \& Sunarsih, D. (2020). Social and Management Research Quantitative Analysis for Medium Sample: Comparing of Lisrel, Tetrad, GSCA, Amos, SmartPLS, WarpPLS, and SPSS. Jurnal Ilmiah Ilmu Administrasi Publik: Jurnal Pemikiran Dan Penelitian Administrasi Publik, 9(2), 518-532. https://ojs.unm.ac.id/iap/article/view/22804

Purwanto, A., Asbari, M., Santoso, T. I., Sunarsi, D., \& Ilham, D. (2021). Education Research Quantitative Analysis for Little Respondents: Comparing of Lisrel, Tetrad, GSCA, Amos, SmartPLS, WarpPLS, and SPSS. Jurnal Studi Guru Dan Pembelajaran, 4(2), 335-350. https://e-journal.my.id/jsgp/article/view/1326

Putra, E. D., Cho, S., \& Liu, J. (2017). Extrinsic and intrinsic motivation on work engagement in the hospitality industry: Test of motivation crowding theory. Tourism and Hospitality Research, 17(2), 228-241. https://doi.org/10.1177/1467358415613393

Putra, F., Asbari, M., Purwanto, A., Novitasari, D., \& Santoso, P. B. (2021). Linking Social Support and Performance in Higher Education. International Journal of Social and Management Studies (IJOSMAS), 01(01), 64-73. https://doi.org/https://doi.org/10.5555/ijosmas.v2i1.8

Ramsey, J. R., Rutti, R. M., Lorenz, M. P., Barakat, L. L., \& Sant'anna, A. S. (2017). Developing global transformational leaders. Journal of World Business, 52(4), 461-473.

https://doi.org/10.1016/j.jwb.2016.06.002

Rezvani, A., Khosravi, P., \& Dong, L. (2017). Motivating users toward continued usage of information systems: Self-determination theory perspective. Computers in Human Behavior, 76, 263-275. https://doi.org/10.1016/j.chb.2017.07.032

Rigby, C. S., \& Ryan, R. M. (2018). Self-Determination Theory in Human Resource Development: New Directions and Practical Considerations. Advances in Developing Human Resources, 20(2), 133-147. https://doi.org/10.1177/1523422318756954

Ryan, R. M., \& Deci, E. L. (2020). Intrinsic and extrinsic motivation from a self-determination theory perspective: Definitions, theory, practices, and future directions. Contemporary Educational Psychology, xxxx, 101860. https://doi.org/10.1016/j.cedpsych.2020.101860

Silitonga, N., Novitasari, D., Sutardi, D., Sopa, A., Asbari, M., Yulia, Y., Supono, J., \& Fauji, A. (2020). The Relationship of Transformational Leadership, Organizational Justice and Organizational Commitment: a Mediation Effect of Job Satisfaction. Journal of Critical Reviews, 7(19), 89-108. http://www.jcreview.com/?mno=101999

Singgih, E., Iskandar, J., Goestjahjanti, F. S., Fahlevi, M., Nadeak, M., Fahmi, K., Anwar, R., Asbari, M., \& Purwanto, A. (2020). The Role of Job Satisfaction in the Relationship between Transformational Leadership, Knowledge Management, Work Environment and Performance. Solid State Technology, 63(2s), 293-314. http://www.solidstatetechnology.us/index.php/JSST/article/view/1556

Sudiyono, R. N., Goestjahjanti, F. S., Asbari, M., Agistiawati, E., Fayzhall, M., Yani, A., Winanti, W., Yuwono, T., Nurasiah, N., \& Yulia, Y. (2020). Meningkatkan Komitmen dan Kinerja Dosen: Apa Peran Manajemen Perguruan Tinggi? EduPsyCouns: Journal of Education, Psychology and Counseling, 2(1), $337-352$.

Sutardi, D., Novitasari, D., Asbari, M., Silitonga, N., Nugroho, Y. A., Hutagalung, D., Mustofa, Chidir, G., Basuki, S., \& Yuwono, T. (2020). Pengaruh Work-Family Conflict, Stres Kerja dan Social Support terhadap Kepuasan Kerja: Studi Kasus pada Guru Wanita di Tangerang. EduPsyCouns: Journal of Education, Psychology and Counseling, 2(1), 482-498. https://ummaspul.e-journal.id/Edupsycouns/article/view/513

Waruwu, H., Johan, M., Asbari, M., Supriatna, H., \& Novitasari, D. (2021). Employee Coaching: Katalisator Kreativitas dan Kinerja Pegawai? Value: Jurnal Manajemen Dan Akuntansi, 16(2), 69-83.

Weller, I., Süß, J., \& Wangenheim, F. Von. (2019). Transformational Leadership , High-Performance Work 
4040 Quo Vadis Motivasi Intrinsik Pegawai: Peran Strategis Kepemimpinan Transformasional dan Kepuasan Kerja - Muhamad Agung Ali Fikri, Masduki Asbari, Dhaniel Hutagalung, Lala Hucadinota Ainul Amri, Dewiana Novitasari

DOI: https://doi.org/10.31004/edukatif.v3i6.1397

System Consensus, and Customer Satisfaction. XX(X), 1-29.

https://doi.org/10.1177/0149206318817605

Yuwono, T., Novitasari, D., Asbari, M., Sutardi, D., Mustofa, \& Asbari, M. (2020). Peran Organizational Commitment terhadap Hubungan Work- Family Conflict dan Kepuasan Kerja Karyawan Wanita di Kota Seribu Industri Tangerang. EduPsyCouns: Journal of Education, Psychology and Counseling, 2(1), 524-540. https://ummaspul.e-journal.id/Edupsycouns/article/view/526/303

Yuwono, T., Novitasari, D., Hutagalung, D., Sasono, I., Silitonga, N., \& Asbari, M. (2020). Peran Organizational Justice terhadap Komitmen Organisasional: Analisis Mediasi Kepuasan Kerja Dosen Perguruan Tinggi Swasta. EduPsyCouns: Journal of Education, Psychology and Counseling, 2(1), 582 599. https://ummaspul.e-journal.id/Edupsycouns/article/view/550

Zaman, M. N., Novitasari, D., Goestjahjanti, F. S., Fahlevi, M., Nadeak, M., Fahmi, K., Setiawan, T., \& Asbari, M. (2020). Effect of Readiness to Change and Effectiveness of Transformational Leadership on Workers ' Performance during Covid-19 Pandemic. Solid State Technology, 63(1s), 185-200. http://www.solidstatetechnology.us/index.php/JSST/article/view/708 